\title{
Comparing the language policies and the students' perceptions of CLIL in tertiary education in Spain and Japan ${ }^{1,2}$
}

\author{
Keiko Tsuchiya ${ }^{a *}$, María D. PÉrez Murillo ${ }^{b}$ \\ ${ }^{a}$ Tokai University, Tokyo, Japan \\ ${ }^{b}$ Complutense University of Madrid, Madrid, Spain \\ * Corresponding author: ktsuchiya@tokai-u.jp
}

ABSTRACT

Content and language integrated learning (CLIL) has been widely implemented in educational systems in Europe since the mid-1990s based on their multilingual education policy. CLIL integrates acquisition of subject knowledge with language learning, either a second or foreign language, simultaneously. Recently, CLIL in English has been introduced in higher education in Japan although its implementation is still at an early stage. This article aims to provide a brief overview of CLIL in higher education in Spain and in Japan in relation to the social economic rationales, and to investigate students' perceptions of CLIL implementation in the two countries through questionnaire surveys. The results show differences in social economic rationales of CLIL implementation in both countries. CLIL in Spain, on the one hand, is 'proactive', adhering to the bilingual and multilingual education policy in the European Union. In Japan, on the other hand, introduction of CLIL seems to be 'reactive' to provide human resources with English proficiency for its economic purposes. In terms of students' perceptions, about a half of the respondents in both countries shows a positive view of CLIL at tertiary level.

Keywords:

CLIL; tertiary education; bi/multilingualism; Spain; Japan; students' perceptions of CLIL.

\section{RESUMEN}

El aprendizaje integrado de contenidos y lengua extranjera (AICLE) se está implantando extensamente en los sistemas educativos de la Unión Europea desde mediados de la década de los noventa, basándose en su política de educación multilingüe. AICLE integra la adquisición simultánea de conocimientos de las distintas materias con el aprendizaje de un idioma, ya sea una segunda lengua o lengua extranjera. Recientemente, el enfoque AICLE en inglés se ha introducido en Japón en la enseñanza superior, aunque su aplicación está todavía en una etapa temprana. Este artículo tiene como objetivo proporcionar una breve visión del enfoque AICLE en la educación superior tanto en España, como en Japón e investigar las percepciones de los estudiantes sobre la implantación de AICLE en los dos países, mediante encuestas basadas en cuestionarios. Los resultados muestran diferencias en los aspectos socio-económicos de la implantación de AICLE en ambos países: mientras que AICLE en España es "proactivo" (Coyle, Hood \& Marsh 2010), siguiendo la política de educación bilingüe y multilingüe de la Unión Europea. En Japón, sin embargo, la adopción de AICLE parece ser "reactiva", es decir, su fin es proporcionar recursos humanos con dominio del inglés con fines meramente económicos. En cuanto a la percepción de los estudiantes, aproximadamente la mitad de los encuestados de ambos países muestran una visión positiva de AICLE en la enseñanza superior.

Palabras claves:

AICLE; educación terciaria; bi-/multilingüismo; España; Japón; percepciones de estudiantes sobre el AICLE.

\section{INTRODUCTION}

Content language integrated learning (CLIL) is defined as 'a dual-focused educational approach in which an additional language is used for the learning and teaching of both content and language' (Mehisto, Marsh, \& Frigols, 2008, p. 9). ${ }^{3}$ Some CLIL scholars claim that the integration of content and language learning distinguishes CLIL from other existing approaches, such as immersion, whose main focus is content learning, and content-based instruction, which is one of the approaches in the framework of language education, although CLIL shares many educational practices with existing approaches (Coyle, Hood, \& Marsh, 2010, p. 1). While other scholars claim that CLIL is placed in the middle of a continuum between approaches of English as a foreign language (EFL), which emphasizes structural learning, and the other polar, those of English as a second language (ESL), which encourages natural language acquisition (Izumi, Ikeda and Watanabe, 2012, p. 2). CLIL is also used as an umbrella

\footnotetext{
${ }^{1}$ A part of this study was presented at the 19th Conference of the Pan-Pacific Applied Linguistics in August 2014 at Waseda University in Tokyo, Japan.

${ }^{2}$ This study was supported in part by the Research and Study Program of Tokai University Educational System General Research Organization and JSPS Grant-in-Aid for Young Scientists (B) No. 26870599. We would like to thank teachers and students in Madrid and Kanagawa for their generous support and participation in this study.

${ }^{3}$ Additional language here refers to languages such as foreign language, second language, heritage language and community language (Coyle, Hood, \& Marsh, 2010, p. 2).
} 
term to include all the approaches from immersion to student exchanges (Mehisto et al., 2008, p. 13). It is not our intention to provide a finer definition of CLIL in this article; however, we need to define what is meant by CLIL here. We take one of the definitions of CLIL in Ikeda (2013), which was described as a typical CLIL, where 'academic subjects such as geography or science are taught in English by non-native content teachers' (p. 31), since it reflects the context of CLIL implementations we investigate in this study. English medium instruction (EMI) classes are included in the definition of CLIL.

CLIL was first introduced in European countries in the mid-1990s to adhere European Union's (EU) multilingual policies. The European Commission (1995, p. 47) explicitly states that their citizens should acquire 'at least two community languages in addition to their mother tongue'. Recently CLIL has also been taken in language education in primary, secondary and tertiary levels in Asian countries as Sasajima (2012) reports some CLIL implementations in Malaysia and in Japan. How CLIL could be implemented at university in Japan is of my central interest. To investigate the issue, this study addresses two research principles:

1. to provide brief reviews on language policies and CLIL implementations in Europe, especially focusing on Spain, which is one of the leading countries in CLIL research, and in Japan respectively;

2. to investigate students' perceptions of CLIL at tertiary level through a questionnaire survey in both countries. We decided to conduct this comparative study at two universities, one in Kanagawa, Japan and the other in Madrid, Spain, since one language is dominantly used in daily life in the two cities: Japanese in Kanagawa, and Castilian is the only official language in Madrid. In addition, both universities provide English-medium CLIL courses. To have an overview of the social economic rationales of CLIL, the following section will provide brief reviews of language policies in Spain and in Japan respectively.

\section{CLIL and language policies ${ }^{4}$}

\section{Language policies in Spain}

CLIL in primary and secondary education in the EU was received by its policy makers with 'great expectations' (Bonnet \& Dalton-Puffer, 2013) as expressed in the Commission of the European Communities (2003).

Content and language integrated learning (CLIL) [...] has a major contribution to make to the Union's language learning goals. It can provide effective opportunities for pupils to use their new language skills now, rather than learn them now for use later. It opens doors on languages for a broader range of learners, nurturing self-confidence in young learners and those who have not responded well to formal language instruction in general education. It provides exposure to the language without requiring extra time in the curriculum [...]. (Commission of the European Communities, 2003, p. 8; cited in Bonnet \& Dalton-Puffer, 2013, p. 270)

CLIL is not directly mentioned in the section of higher education in the Commission of the European Communities (2003). Instead, it warns the pervasive use of English as a medium of institution at universities and encourages the promotion of the national or regional languages to maintain linguistic diversity.

In non-Anglophone countries recent trends to provide teaching in English may have unforeseen consequences on the vitality of the national language. University language policies should therefore include explicit actions to promote the national or regional language. (Commission of the European Communities, 2003, p. 8)

The focus here is placed on CLIL in English in higher education in Spain, which has led CLIL research and its implementations.

Spain is a multilingual nation that includes several autonomous communities with different official languages, such as Castilian (Spanish), Catalan, Valencian, and Basque. In the European Union (EU) including Spain, several superagencies, i.e. the European Commission, the Council of Europe and the Commission of European Communities, supervise language policies to the ministry of education in each country. There were four major policies that affected the introduction of CLIL (Fortanet-Gómez 2013, pp. 72-73). In 1982, the Council of Europe established principles to improve multilingual education of modern European languages (Council of Europe,

${ }^{4}$ An early version of the overview was published in Japanese in Tsuchiya (2014).

Tsuchiya, K., \& Pérez Murillo, M. D. (2015). Comparing the language policies and the students' perceptions of CLIL in tertiary education in Spain and Japan. Latin American Journal of Content and Language Integrated Learning, 8(1), 25-35. doi:10.5294/laclil.2014.8.1.3 elSSN 2322-9721. 
1982), which was followed by the introduction of the Common European Framework of Reference for Languages (CEFR) (Council of Europe 2001). The Bologna Declaration in 1999 and the Action Plan 2004-2006 in 2003 also served as driving forces to implement CLIL in their education systems (European Commission 1999). The former defined a common framework for degree systems in the EU countries, which enabled higher institutions to exchange their credits, and improved the mobility of their students and staffs among the nations (European Commission, 1999; Smit \& Dafouz, 2012). The latter explicitly stated that the higher education played an important role to improve multilingual policies and encouraged the universities to provide exchange programmes for all the students to stay other countries at least for a term, requiring them to obtain language certificates after the programmes (Commission of the European Communities, 2003). Furthermore, the Bologna Process was presented in 2010 to review the progress of the Bologna Declaration and to provide the policies for the future. Simultaneously, the European Higher Education Area was enacted to improve the further exchange of the students among the nations (European Commission 2010).

These policies have enhanced bi/multilingual education in Spain, and it is reported that 34 out of 77 universities in Spain now have bi/multilingual programmes which are taught in two official languages and one other language, English in many cases (García 2013). Some universities in bilingual communities in Spain introduced their own multilingual policies that advocate the use of both community languages and English in higher education. Universitat Jaume I in Valencia, for example, adopted the policy which enhances the opportunities to learn and use both Valencian and English in addition to Castilian, providing the same amount of lectures in Valencian and Castilian, and some lectures in English (12 credits in 240 credits in total) (FortantGómez, 2013, p. 221). Another study that the British Council conducted shows that, out of 55 countries, English medium instruction is allowed in $78.2 \%$ of public universities and $90.9 \%$ of private universities (Spain, 2015, based on Dearden, 2014).

The university in Madrid at which we conducted this study in 2013 and 2014 also offers a Master's course in English Language Teaching that is taught only in English and a bilingual strand in an undergraduate course in primary education that is taught in English and Spanish. One of the factors which made this possible is the success of bi/multilingual schools in primary and secondary education as reported in the Bilingual Education Project in Spanish (BEP) in Madrid, for example, which started in 1996 by the local government and the British Council (Dobson, Pérez Murillo \& Johnstone, 2010). Under this project, 26 schools in Madrid implemented bilingual education in Spanish (Castilian) and English (ibid), and some of the students in the bilingual class at the university were graduates of the bilingual primary and secondary schools.

In the EU countries such as Spain, CLIL was introduced to implement their multilingual policies since multilingual skills are seen as the key to improve mutual understanding in the multi-ethnic communities and also to promote the mobility of EU citizens in the global contexts. CLIL in Spain, therefore, could be 'proactive' (Coyle, Hood, \& Marsh, 2010), promoting the bilingual and multilingual education. For comparison, language policies in Japan in relation to the introduction of CLIL will be briefly described in the following section.

\section{Language policies in Japan}

English education in primary and secondary schools in Japan has faced major changes in the recent years: 'foreign language activities', which are not a subject class but an activity in a foreign language, English in principle, have introduced in the fifth and sixth grade levels of primary school in 2011, and English classes in upper secondary schools are suggested to be taught in English from 2013, following the course of study issued in 2008 (MEXT, 2008). The updated action plan (MEXT, 2013) is pushing the English education reform even further, planning to start 'foreign language activities' in the third and fourth grades of primary school, to teach English as a subject from the fifth grade, and to suggest that English classes in lower secondary schools should also be taught in English. These plans are expected to be enacted within a few years.

The promotion of English medium instruction (EMI) classes at tertiary level education in Japan has been included in the national educational policies in the last decade to respond to the criticism on the insufficient English education and the globalisation in its economy (Brady, 2008, p. 97; Butler-Goto \& Iino, 2005; Smit \& Dafouz, 2012; Tanabe, 2003). The strategic plan to cultivate 'Japanese with English abilities' was designed by the Ministry of Education, Culture, Sports, Science and Technology in the early 2000s (MEXT, 2002). The Action Plan,

Tsuchiya, K., \& Pérez Murillo, M. D. (2015). Comparing the language policies and the students' perceptions of CLIL in tertiary education in Spain and Japan. Latin American Journal of Content and Language Integrated Learning, 8(1), 25-35. doi:10.5294/laclil.2014.8.1.3 elSSN 2322-9721. 
which was issued in the following year, stated that communication skills in English are crucial to survive in the globalised society in the 21st century and urged institutions in higher education to improve and reform their education schemes in order to develop human resources who can actively work in global contexts using English immediately after graduation (MEXT 2003).

To drive the university reform, the government offered intensive support to universities that promote study abroad programmes for their students and provide lectures in English. EMI lectures at universities are also encouraged to attract students inside and outside of Japan to higher education in Japan (MEXT, 2011).

Amid ongoing globalization, in order to develop an educational environment where Japanese people can acquire the necessary English skills and also international students can feel at ease to study in Japan, it is very important for Japanese universities to conduct lessons in English for a certain extent, or to develop courses where students can obtain academic degrees by taking lessons conducted entirely in English. [...] Of course, such universities still also provide substantial Japanese-language education courses. (MEXT, 2012)

The policy encourages the use of English, and simultaneously emphasises the importance of the national language, Japanese, as a medium of instruction in higher education in order to enhance opportunities for Japanese students to acquire English skills and to increase the number of international students. It seems obvious that the policy does not concern bi/multilingualism in the society for mutual understanding among different ethnicities, which is a noticeable difference from the EU policies previously reviewed in this paper. Some strategic plans were enacted for the internationalisation of universities in Japan in 2008; '300,000 International Students Plan', which aims to host 300,000 international students at universities in Japan by 2020, and 'Global 30', which is the programme to develop thirty universities as centres for internationalisation (Global 30) (MEXT, 2012; MEXT, 2009). The latter is currently called as 'The Top Global University Project', providing funding to 37 universities selected in 2014 (MEXT, 2014). These also correspond to the government-industry-academia strategic plan to provide 'global human resources', which has been an urgent demand for Japan's economy (METI, 2010). Thus, in Japan, the introduction of CLIL seems to be 'reactive' (Coyle, Hood, \& Marsh, 2010), responding to the criticism on the previous English education system and the demands of its globalised economy.

Following these language polices and reforms, it is reported about $30 \%$ of universities now provide subject classes in English, and 26 undergraduate and 174 graduate schools offer courses where students can obtain degrees by taking English-mediated classes (MEXT 2011). Some studies report implementations of CLIL in higher education in Japan, i.e. learning health sciences in CLIL at Saitama Medical University (Sasajima, 2011), and one year course which combines a half-year EAP (English for Academic Purpose) course and another half-year CLIL courses focusing on environmental issues and global economics at Sophia University (Izumi et al., 2012). However, the CLIL implementation and research in Japanese universities are still limited (Ikeda, Pinner, Mehisto, \& Marsh, 2013). The following section will report the results of a preliminary survey to investigate students' perception of CLIL at universities in Spain and in Japan.

\section{METHODS}

A questionnaire survey was conducted to obtain students' internal views of CLIL classes in higher education in Madrid, Spain, and in Kanagawa, Japan, in 2013 and 2014. Before we conducted the questionnaire survey at the university in Madrid, we observed classes in the graduate and undergraduate courses. There were about twenty to thirty students including a few international students from European and Asian countries, and the lecturers were $\mathrm{bi} /$ multilinguals, most of whom were native speakers of Spanish (Castilian). The lecturers used only English in the classes and so did the students. Similarly, the lecturer in the CLIL class at the Japanese university used English most of the time. The difference is that there were 15 to 20 students, all of whom were Japanese.

The total number of respondents was 159: 129 Spanish students and 30 Japanese students. ${ }^{5}$ All of them were undergraduate students in their second or third year. Among the 129 Spanish students, 46 students were enrolled in the bilingual strand (Bilingual) in primary education at a university in Madrid, where the medium of instruction

\footnotetext{
${ }^{5}$ We excluded the responses from the international students in the analysis since their educational backgrounds vary and the focus of this study was placed on the local students in Madrid, Spain, and in Kanagawa, Japan.
} tertiary education in Spain and Japan. Latin American Journal of Content and Language Integrated Learning, 8(1), 25-35. doi:10.5294/laclil.2014.8.1.3 elSSN 2322-9721. 
was English, and 83 students took the same course in Castilian although they also had a few subject classes taught in English, which was the main stream at the university (Mainstream). The 30 Japanese students (Japanese) studied in the department of arts and sciences at a university in Kanagawa, Japan, and experienced at least one CLIL class in English. All the Japanese students attended an undergraduate course in English Language Teaching, which was an English-medium CLIL class and a compulsory module for the students who wish to obtain the certificate to become secondary school English teachers in Japan.

Thus, there are three groups of the respondents:

- Bilingual: Spanish undergraduate students in the bilingual strand at a university in Madrid.

- Mainstream: Spanish undergraduate students in the mainstream course at a university in Madrid.

- Japanese: Japanese undergraduate students at a university in Kanagawa, Japan.

The questionnaire survey, which was developed on the basis of Fortanet-Gómez (2013), included the questions about students' personal backgrounds (course they enrolled and countries they have lived), their language repertoire (their first, second and other languages, and the use of those languages in everyday life), and their perceptions towards CLIL, asking whether they think subject classes should be taught both in their L1 and English in primary, secondary and tertiary levels using a Likert scale with five points, and what they think are advantages and disadvantages of CLIL at higher education.

The following were the questions on the questionnaire for the Spanish students:

- $\quad$ Personal backgrounds

Q1. Programme you are enrolled in and your grade.

Q2. Countries you have lived.

Q3. Are you an international student?

- Language repertoire

Q4. Your first language (L1), second language (L2) and other languages.

Q5. Your use of languages in family meetings, friends' meetings, and TV/the Internet.

- $\quad$ Subject classes in English

Q6. Do you agree with the following statements? ${ }^{6}$

(Likert-scale: " 1 " means you do not agree and " 5 " means you completely agree.)

6-1: Spanish and English should be used as languages of instruction at primary school.

6-2: Spanish and English should be used as languages of instruction at secondary school.

6-3: Spanish and English should be used as languages of instruction at university.

Q7. What do you think are advantages and disadvantages of the subject classes taught in English at university?

In addition, to indicate to what extent they agree with English medium CLIL in primary, secondary and tertiary levels in the Likert-scale in Q6, the respondents were asked to write their opinions about CLIL in English at university in $\mathrm{Q} 7$ in the questionnaires.

\section{RESULTS}

Table 1 and Figure 1 illustrate the results of Q5: languages the students use in family/ friend meetings and on TV/the Internet. In the contexts of family meetings, $67.4 \%$ of the Spanish students in the bilingual class (Bilingual) claim to use only their L1, $13 \%$ of them use L1 and English, and about 20\% of them use English and other languages in addition to their L1. The mainstream group (Mainstream) and the Japanese group (Japanese) show a similar tendency in the use of languages in their family meetings: most of them answer that they use only their L1 (84.3\% in the mainstream group and $86.7 \%$ in the Japanese group). The percentages of the students who claim to use both L1 and English are similar to that of the bilingual group (14.5\% in the mainstream group and 13.3 in the Japanese group), while only one student in the mainstream group and no one in the Japanese group answer that they use

\footnotetext{
${ }^{6}$ For Japanese respondents, we put Japanese (instead of Spanish) at the first part of the question sentences in Q6, i.e. 6-1: Japanese and English should be used as languages of instruction at primary school.
} tertiary education in Spain and Japan. Latin American Journal of Content and Language Integrated Learning, 8(1), 25-35. doi:10.5294/laclil.2014.8.1.3 elSSN 2322-9721. 
L1, English and other languages in family meetings, which is a difference from the bilingual group, $19.6 \%$ of whom seem to have a third language in addition to L1 and English to communicate with their family members.

Table 1. What languages do the students use?

L1

(Spanish or

English

L1 and English

L1 and English Japanese) and/or Other

Total Languages

\begin{tabular}{|c|c|c|c|c|c|c|c|c|c|c|}
\hline \multirow{3}{*}{\multicolumn{2}{|c|}{$\begin{array}{c}\text { Family Bilingual } \\
\text { meeting Mainstream } \\
\text { Japanese }\end{array}$}} & 31 & $67.4 \%$ & 0 & $0.0 \%$ & 6 & $13.0 \%$ & 9 & $19.6 \%$ & 46 \\
\hline & & 70 & $84.3 \%$ & 0 & $0.0 \%$ & 12 & $14.5 \%$ & 1 & $1.2 \%$ & 83 \\
\hline & & 26 & $86.7 \%$ & 0 & $0.0 \%$ & 4 & $13.3 \%$ & 0 & $0.0 \%$ & 30 \\
\hline \multirow{3}{*}{$\begin{array}{l}\text { Friends } \\
\text { meeting }\end{array}$} & Bilingual & 12 & $26.1 \%$ & 0 & $0.0 \%$ & 22 & $47.8 \%$ & 12 & $26.1 \%$ & 46 \\
\hline & Mainstream & 53 & $63.9 \%$ & 0 & $0.0 \%$ & 26 & $31.3 \%$ & 4 & $4.8 \%$ & 83 \\
\hline & Japanese & 22 & $73.3 \%$ & 0 & $0.0 \%$ & 8 & $26.7 \%$ & 0 & $0.0 \%$ & 30 \\
\hline \multirow{3}{*}{$\begin{array}{l}\text { TVI } \\
\text { Internet }\end{array}$} & Bilingual & 1 & $2.2 \%$ & 2 & $4.3 \%$ & 34 & $73.9 \%$ & 9 & $19.6 \%$ & 46 \\
\hline & Mainstream & 12 & $14.5 \%$ & 1 & $1.2 \%$ & 62 & $74.7 \%$ & 8 & $9.6 \%$ & 83 \\
\hline & Japanese & 18 & $60.0 \%$ & 0 & $0.0 \%$ & 12 & $40.0 \%$ & 0 & $0.0 \%$ & 30 \\
\hline
\end{tabular}

Note: Bilingual $=$ Spanish students in the bilingual strand, Mainstream = Spanish students in the mainstream course, Japanese $=$ Japanese students in arts and sciences

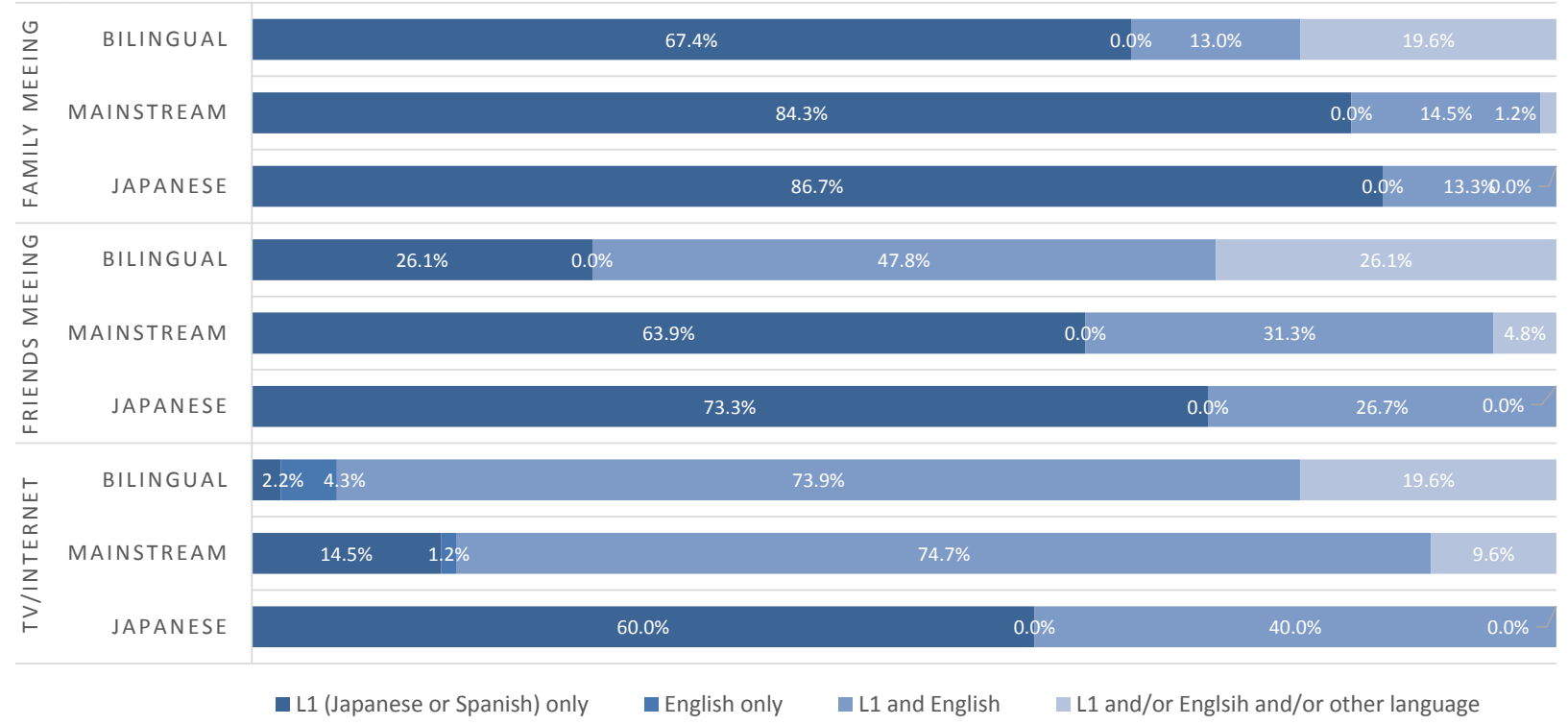

Figure 1. What languages do the students use?

About $74 \%$ of the students in the bilingual group use two or three languages in their friends meetings: $47.8 \%$ in the bilingual group use L1 and English, and 26.1\% use three languages, L1, English and an additional language, to interact with their friends. In contrast, about 60 to $70 \%$ of the students in the mainstream group and the Japanese group seem to use only their L1 in their friends meetings $(63.9 \%$ in the mainstream group and $73.3 \%$ in the Japanese group). A difference was observed between the mainstream group and the Japanese group in the results of the use of languages on TV/the Internet. More than $70 \%$ of the students in the bilingual group and the mainstream group watch TV and use the Internet in L1 and English. However, the percentage decreases in the Japanese group to $40 \%$ and $60 \%$ of them claim that they use only their L1 when they watch TV or use the Internet. 
The results indicate that the students in the bilingual group seem to have multilingual environments around them in everyday life, while the use of other languages apart from L1 is limited in the other two groups.

Table 2 and Figure 2 show the results of Q6: the degree to which the students agree with the subjects classes taught both in L1 and English in primary, secondary, and tertiary education.

Table 2. Students' perceptions of CLIL.

\begin{tabular}{|c|c|c|c|c|c|c|c|c|c|c|c|c|c|c|}
\hline & & & 1 & & & & & & & & 5 & & & \\
\hline & & $\begin{array}{r}\text { Cor } \\
\mathrm{Di}\end{array}$ & $\begin{array}{l}\text { pletely } \\
\text { agree }\end{array}$ & & 2 & & 3 & & 4 & $\begin{array}{r}\text { Con } \\
\mathrm{A}\end{array}$ & $\begin{array}{l}\text { pletely } \\
\text { gree }\end{array}$ & & $N / A$ & Total \\
\hline Primary & Bilingual & 0 & $0.0 \%$ & 0 & $0.0 \%$ & 4 & $8.7 \%$ & 13 & $28.3 \%$ & 29 & $63.0 \%$ & 0 & $0.0 \%$ & 46 \\
\hline & Mainstream & 4 & $4.8 \%$ & 6 & $7.2 \%$ & 9 & $10.8 \%$ & 19 & $22.9 \%$ & 44 & $53.0 \%$ & 1 & $1.2 \%$ & 83 \\
\hline & Japanese & 7 & $22.6 \%$ & 2 & $6.5 \%$ & 8 & $25.8 \%$ & 5 & $16.1 \%$ & 7 & $22.6 \%$ & 2 & $6.5 \%$ & 31 \\
\hline Secondan & Bilingual & 2 & $4.3 \%$ & 0 & $0.0 \%$ & 4 & $8.7 \%$ & 12 & $26.1 \%$ & 28 & $60.9 \%$ & 0 & $0.0 \%$ & 46 \\
\hline & Mainstream & 2 & $2.4 \%$ & 3 & $3.6 \%$ & 12 & $14.5 \%$ & 22 & $26.5 \%$ & 44 & $53.0 \%$ & 0 & $0.0 \%$ & 83 \\
\hline & Japanese & 6 & $19.4 \%$ & 1 & $3.2 \%$ & 2 & $6.5 \%$ & 10 & $32.3 \%$ & 10 & $32.3 \%$ & 2 & $6.5 \%$ & 31 \\
\hline Tertiary & Bilingual & 3 & $6.5 \%$ & 0 & $0.0 \%$ & 9 & $19.6 \%$ & 8 & $17.4 \%$ & 25 & $54.3 \%$ & 1 & $2.2 \%$ & 46 \\
\hline & Mainstream & 4 & $4.8 \%$ & 10 & $12.0 \%$ & 17 & $20.5 \%$ & 16 & $19.3 \%$ & 36 & $43.4 \%$ & 0 & $0.0 \%$ & 83 \\
\hline & Japanese & 3 & $9.7 \%$ & 2 & $6.5 \%$ & 1 & $3.2 \%$ & 9 & $29.0 \%$ & 14 & $45.2 \%$ & 2 & $6.5 \%$ & 31 \\
\hline
\end{tabular}

Note: Bilingual $=$ Spanish students in the bilingual strand, Mainstream $=$ Spanish students in the mainstream course, Japanese $=$ Japanese students in arts and sciences

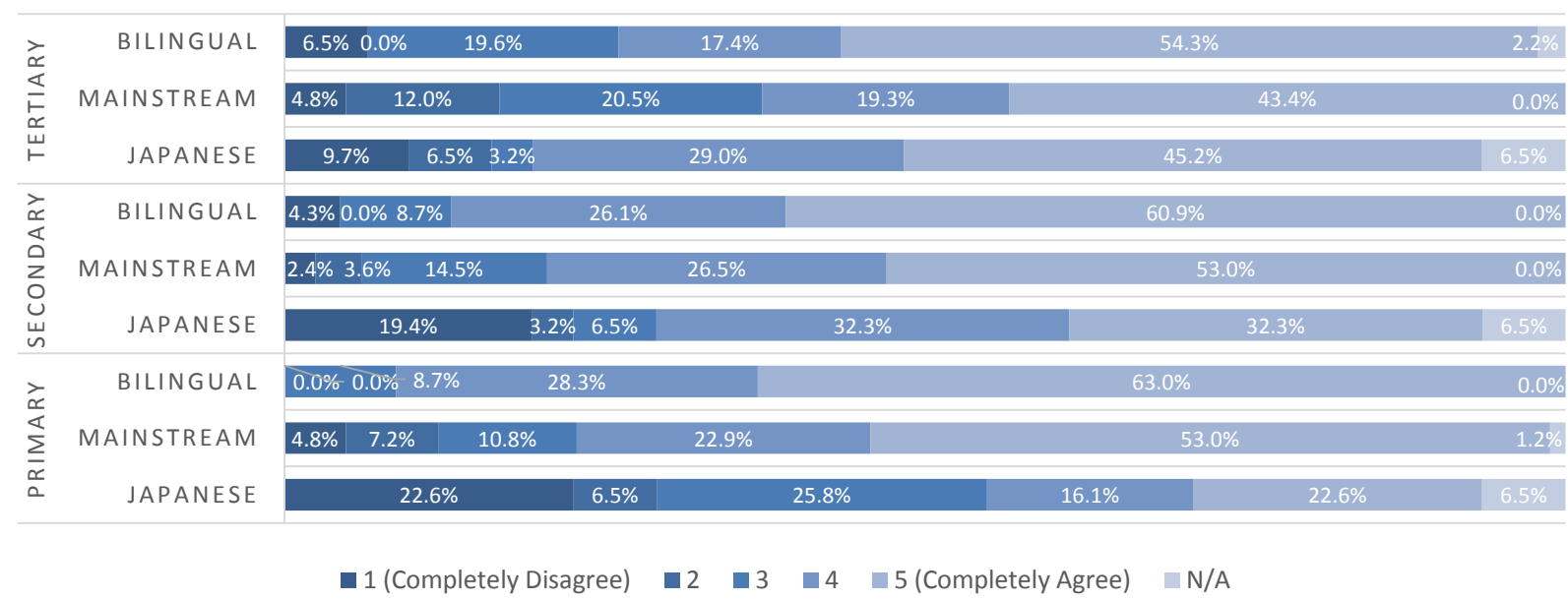

Figure 2. Students' perceptions of CLIL

There are differences in their perceptions of CLIL at primary and secondary education between the Spanish students in the two groups and the Japanese group. Most of the students in the Bilingual group and the mainstream group show their strong agreement with subject classes both in L1 and English in primary and secondary schools: more than $90 \%$ of the students in the bilingual group rate 4 or 5 for CLIL in primary education and about $87 \%$ in secondary education, and approximately $75 \%$ of the students in the mainstream group rate 4 or 5 for CLIL in primary education and $80 \%$ in secondary education. The Japanese students, on the other hand, express more conservative views towards CLIL classes in English in primary and secondary levels: about $39 \%$ of them rate 4 or 5 in primary education and $65 \%$ in secondary education. It should be noted, however, that the results might be affected by the fact that the Spanish students in the two groups studied primary education and some of them were aiming to teach at bilingual primary or secondary schools after graduation. 
Interestingly, the opposite tendency was observed in their perceptions of English medium CLIL in tertiary level. About $70 \%$ of the bilingual group and $62 \%$ of the mainstream group rate 4 or 5 for CLIL in tertiary education, which are lower by about 20 percentage points than those for primary and secondary education. While about $75 \%$ of the Japanese students, rate 4 or 5 for CLIL in higher education. This chimes with the findings in Tsuchiya (2014), which reports a preliminary CLIL implementation project at a Japanese university and the students' positive perception of the course.

\section{DISCUSSION}

Some students expressed concerns on the implementation of English medium CLIL at university were raised by the respondents in Q7 in the questionnaire: What they think are advantages and disadvantages of subject classes taught in English at university. The comments from the respondents include concerns on:

- the importance of English for their future careers,

- students' lack of English skills to understand subject contents,

- the risk of losing opportunities to learn subjects in their L1,

- teachers without adequate English skills to teach subjects,

- the need to improve CLIL curricula and assessment systems.

Many students in both countries assume that CLIL in English help students improve their English skills, but at the same time, they are aware of the difficulties they might face to understand the contents of the subjects if their English level is not sufficient. The following is the comment provided by SS1 (3rd year Spanish student in the bilingual group):

I think the advantages are many because many jobs require a good English level, so this will help to acquire it, specially [sic] more specialised vocabulary related with what you are studying. The disadvantages could be that many people do not have a good starting level [of English], so they may find it very difficult. An idea could be to receive complementary English courses. (SS1: 3rd year Spanish student in the bilingual class)

As shown in SS1's comments, many Spanish students seem to be aware of the importance of English skills for their future careers. The difficulties to understand the content in English and their worries about their level of English were more explicitly expressed in JS1's (2nd year Japanese student) comment below.

I prefer classes in Japanese. I don't have so much vocabulary, so it's hard for me. (JS1: 2nd year Japanese student)

Based on Cummins (1984), Coyle et al. (2010, p. 68) illustrate the relationship between 'linguistic demands' and 'cognitive demands', which are required in CLIL classrooms as shown in the matrix in Figure 3. As the solid line in the figure illustrates, teachers should organise activities in classrooms to start with a task with low linguistic and cognitive demands (Task a), and then lead learners to a task with high linguistic and cognitive demands (Task d) though several steps (Tasks b and c).

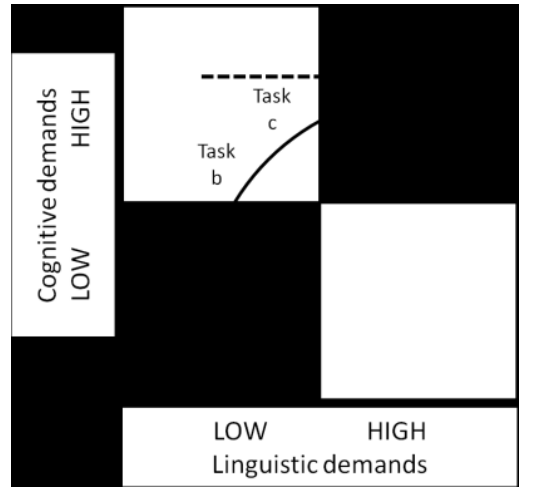

Figure 3. The CLIL matrix (after Coyle et al., 2010, p. 68; the dashed line was added by the present authors).

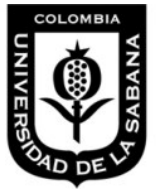

Tsuchiya, K., \& Pérez Murillo, M. D. (2015). Comparing the language policies and the students' perceptions of CLIL in tertiary education in Spain and Japan. Latin American Journal of Content and Language Integrated Learning, 8(1), 25-35. doi:10.5294/laclil.2014.8.1.3 elSSN 2322-9721. 
It has been pointed out that it is particularly challenging 'to progress from low to high linguistic demands whilst maintain high levels of cognitive demand' (Coyle et al., 2010), as illustrated in the dashed line in Figure 3. This precisely describes the difficulties in teaching and learning in CLIL at tertiary level, where students have high cognitive skills in their L1 although they may not have enough English skills to process tasks with high cognitive and linguistic demands. The challenge to teach cultural studies in a CLIL approach to students with lower linguistic skills at a university in Spain was reported in Spies (2012), who suggests that CLIL lecturers at universities first provide tasks with high cognitive and low linguistic demands, and then increase the linguistic demands accordingly. Fernandez-Santiago (2011) also recognises the issue and indicates the potential of CLIL to improve English skills of lower level students to contrast to immersion courses, where students with advanced English skills seem to have benefits.

Although the number is limited, few students in both countries express their concerns on the potential risk to become incapable of understanding subject contents in L1 when they take subject classes in English. Although what JS2 (3rd year Japanese student) means by 'technical subjects' in the comment below, it is obvious that s/he has a preference to be taught certain subjects in their L1, Japanese.

It depends on the contents of the class. Technical subjects should be taught in Japanese. (JS2: 3rd year Japanese student)

SS2 (3rd year Spanish student in the bilingual class) also provides a similar concern, referring their own experiences of learning subjects in English.

Advantages: we learn English in a concrete way, as a way of communicate a content [sic].

Disadvantages: we sometimes don't know some terms in Spanish.

(SS2: 3rd year Spanish student in the bilingual class)

Other issues on the CLIL courses were also raised by some Spanish students, i.e. the lack of the trained teachers and shared evaluation schemes for the CLIL courses. These highlight important areas for further research in CLIL implementation at tertiary level.

\section{CONCLUSION}

This article started with the brief overviews of the language policies in Europe, especially Spain, and Japan, in the last two decades. There are some differences in the policies which have promoted the introduction of CLIL in their education systems in the two countries: In the EU countries, CLIL was implemented to enhance multilingualism, mutual understanding in the multiethnic society and the mobility of its citizens. While CLIL in Japan was introduced in response to the criticism on the previous English education schemes and the urgent demands of human resources with English abilities from its globalised economy without considerations on bi/multilingualism in the society.

The results from the questionnaire survey show that most of the Spanish students in the two groups agree with English medium CLIL in primary and secondary education, while the majority of the Japanese students have a conservative view towards CLIL implementation in primary and secondary levels. The students in both countries express a relatively positive view towards CLIL in higher education. However, it is still controversial as some students critically addressed various concerns and difficulties in implementation of CLIL at universities i.e. their insufficient English skills to understand subjects and the potential risk to lack subject knowledge in L1.

Differences in social and economic rationales behind CLIL implementations between the two nations were revealed, and the language policies and CLIL in Europe cannot be imported as it is to the educational context in Japan. However, it could be worth learning the conceptual frameworks of the policies in the EU and its processes to promote multilingualism and the mobility of the citizens in the EU in order to improve the linguistic policies and the practices in Japan. CLIL in Japan should not be a mere strategy to provide human resources to fill economic demands, rather it could contribute to improve coexistence in the complex multilingual and multicultural society if it is implemented and organised with careful considerations.

Further studies should be conducted with a larger set of data since the number of the respondents to the questionnaire survey is small, and we could include interviews or focus groups discussions with students as 
methodologies to have deeper insights in a future study. However, this study indicates that considerations to be paid towards language policies and linguistic environments including students' use of languages in daily life and their previous experiences in school to implement CLIL at tertiary level in individual societies. Some areas for further research were highlighted from the results of the survey on students' perception of CLIL in higher education.

\section{REFERENCES}

Bonnet, A., \& Dalton-Puffer, C. (2013). Great Expectations? Competence and Standard Related Questions Concerning CLIL Moving into the Mainstream. In S. Breidback \& B. Viebrock (Eds.), Content and language integrated learning (CLIL) in Europe: Research perspectives on policy and practice (pp. 269-284). Frankfurt, Germany: Peter Lang.

Butler-Goto, Y., \& Iino, M. (2005). Current Japanese reforms in English language education: the 2003 "Action Plan". Language Policy, 4(1), 25-45.

Commission of the European Communities. (2003). Promoting language learning and linguistic diversity: An action plan 2004-2006. Brussels, Belgium: European Commission. Retrieved from http://eur-lex.europa.eu/legalcontent/EN/TXT/?uri=CELEX:52003DC0449

Council of Europe. (1982). Recommendation No, $R$ (82): 18. Retrieved from https://wcd.coe.int/

Council of Europe. (2001). Common European framework of reference for languages: Learning, teaching, assessment. Cambridge, UK: Cambridge University Press. Retrieved from http://www.coe.int/t/dg4/linguistic/Source/ Framework EN.pdf

Coyle, D., Hood, P., \& Marsh, D. (2010). CLIL: Content and language integrated learning. Cambridge, UK: Cambridge University Press.

Dearden, J. (2014). English as a medium of instruction: A growing global phenomenon. London, UK: British Council. Retrieved from http://www.britishcouncil.org/education/ihe/knowledge-centre/english-languagehigher-education/report-english-medium-instruction

Dobson, A., Pérez Murillo, M. D., \& Johnstone, R. (2010). Bilingual education project: Spain evaluation report. Retrieved from http://www.mecd.gob.es/

European Commission. (1995). White paper on education and learning: Teaching and learning, Towards the learning society. Brussels, Belgium: European Commission. Retrieved from http://europa.eu/ documents/comm/white papers/pdf/com95 590 en.pdf

European Commission. (1999). The Bologna declaration on the European space for higher education. Retrieved from http://ec.europa.eu/

European Commission. (2010). The Bologna process: Towards the European higher education area. Retrieved from http://ec.europa.eu/education/higher-education/bologna en.htm

Fernández-Santiago, M. (2011). Integration or immersion? A comparative study at the tertiary level. Latin American fournal of Content and Language Integrated Learning, 4(1), 49-64. doi:10.5294/laclil.2011.4.1.5

Fortanet-Gómez, I. (2013). CLIL in higher education: Toward a multilingual language policy. Bristol, UK: Multilingual Matters.

García, A. M. R. (2013). Higher education bilingual programmes in Spain. Porta Linguarum, 19, 101-111.

Ikeda, M., Pinner, R., Mehisto, P., \& Marsh, D. (2013). Editorial. International CLIL Research fournal, 2(1).

Ikeda, M. (2013). Does CLIL work for Japanese secondary school students? Potential for the 'weak' version of CLIL. International CLIL Research fournal, 2(1), 31-43.

Izumi, S., Ikeda, M., \& Watanabe, Y. (2012). CLIL (content and language integrated learning): New challenges in foreign language education at Sophia University. Volume 2: Practice and Applications [in Japanese]. Tokyo, Japan: Sophia University Press.

Llinares, A., Morton, T., \& Whittaker, R. (2012). The role of language in CLIL. Cambridge, UK: Cambridge University Press.

Mehisto, P., Marsh, D., \& Frigols, M-J. (2008). Uncovering CLIL: Content and language integrated learning in bilingual and multilingual education. Oxford, UK: Macmillan Education. 
METI (2010). Develop global human resources through industry-academic-government collaboration. Tokyo, Japan: Ministry of Economy, Trade and Industry. Retrieved from http://www.meti.go.jp/

MEXT. (2002) Fapanese government policies in education, culture, sports, science and technology 2002. Tokyo, Japan: Ministry of Education, Culture, Sports, Science and Technology.

MEXT. (2003). An action plan to cultivate 'Japanese with English abilities'. Tokyo, Japan: Ministry of Education, Culture, Sports, Science and Technology Japan.

MEXT. (2009). Global 30. Tokyo, Japan: Ministry of Education, Culture, Sports, Science and Technology Japan. Retrieved from http://www.uni.international.mext.go.jp/

MEXT (2011). Daigaku ni okeru kyoiku naiyou tou no kaikaku jokyo [Reform in higher education]. Retrieved $\mathrm{m}$ http://www.mext.go.jp/a_menu/koutou/daigaku/04052801/1341433.htm

MEXT. (2012). Higher education in fapan. Tokyo, Japan: Higher Education Bureau, Ministry of Education, Culture, Sports, Science and Technology Japan.

MEXT. (2013). English education reform plan corresponding to globalization. Tokyo, Japan: Ministry of Education, Culture, Sports, Science and Technology Retrieved from http://www.mext.go.jp/english/topics/1343591.htm

MEXT. (2014). Selection for the FY 2014 Top Global University Project. Tokyo, Japan: Ministry of Education, Culture, Sports, Science and Technology Japan.

Sasajima, S. (Ed.). (2011). CLIL: Content and language integrated learning [in Japanese]. Tokyo, Japan: Sanshusha.

Smit, U., \& Dafouz, E. (2012). Integrating content and language in higher education: An introduction to Englishmedium policies, conceptual issues and research practices across Europe. AILA Review, 25, 1-12.

Spain, T. (2015). EMI: Situations, Problems and Possible Solutions. Paper presented at the Academic Teaching Excellence Session, Madrid, Spain.

Spies, K. (2012). Intercultural studies within a CLIL approach. Latin American fournal of Content and Language Integrated Learning, 5(1), 33-45. doi:10.5294/laclil.2012.5.1.3

Tanabe, Y. (2004). What the 2003 MEXT Action Plan proposes to teachers of English. The Language Teacher, 28(3), 3-8.

Tsuchiya, K. (2014). Learning intercultural communication in a CLIL classroom [in Japanese]. The Report of Foreign Language Centre, Tokai University, 34, 61-70.

\section{BIODATA}

Keiko TsuchIYA is an Associate Professor of the Foreign Language Centre at Tokai University, Japan, where she teaches intercultural communication, sociolinguistics and academic English. Her research interest includes multimodal corpus analysis, English as a Lingua Franca (ELF), Content and Language Integrated Learning (CLIL) and professional communication, especially in health care and business contexts. She is the author of Listenership Behaviours in Intercultural Encounters: A Time-aligned Multimodal Corpus Analysis (John Benjamins, 2013). She holds a PhD from the University of Nottingham.

María D. Pérez Murillo is an Associate Professor at the School of Education, Complutense University in Madrid (Spain), where she is involved in undergraduate and postgraduate courses of training for prospective teachers. She holds an MA in Applied Linguistics and a PhD in Linguistics in the area of Bilingual Education from Lancaster University, UK. Her research interests include bi/multilingual classroom interaction, bi/multilingual teacher development and CLIL. Her recent publications focus on multilingual literacy (the uses of texts in the classroom) and the evaluation of a bilingual programme (the joint British-Council/Spanish Ministry of Education National Bilingual Project). 